\section{Microbiolization of organic cotton seeds with Trichoderma sp. and Saccharomyces cerevisiae}

\author{
José Manoel Ferreira de Lima $\operatorname{Cruz}^{1 *}$ (D) Eliane Cecília de Medeiros $^{1}$ iD, \\ Otília Ricardo de Farias ${ }^{1}$ (D) Edcarlos Camilo da Silva ${ }^{1}$ (D) , Luciana Cordeiro \\ do Nascimento ${ }^{1}$ (iD
}

ABSTRACT: Seed microbiolization is an alternative to chemical pesticides for seed treatment in organic agriculture. Thus, this study aimed at evaluating the initial growth and control of fungi associated with organic cotton seeds, through seed microbiolization with Trichoderma sp. and Saccharomyces cerevisiae. Certified cotton seeds (cultivar Aroeira), whose linter was removed with sulfuric acid, were analyzed in a completely randomized design in a $5 \times 2$ +1 factorial scheme, corresponding to five concentrations (0, 0.5, 1.0, 1.5, and 2.0), two biocontrol agents (Trichoderma sp. and S. cerevisiae), and an additional treatment composed of a fungicide (Captan $\left.{ }^{\circledR}\right)$. Seed health, germination, and emergence tests were conducted to confirm the hypotheses. The microbiolization of seeds is efficient in reducing both incidence and initial growth of fungi in organic cotton cv. Aroeira. The appraised biocontrol agents proved to be superior to the chemical treatment regarding the initial seedling growth. Trichoderma sp. is the most effective agent and provides a high initial seedling growth and a significant reduction in fungal incidence.

Index terms: Gossypium hirsutum, biocontrol agents, initial growth, biological control, growth stimulation.

\section{Microbiolização de sementes de algodoeiro orgânico com Trichoderma sp. e Saccharomyces cerevisiae}

RESUMO: A microbiolização de sementes é uma alternativa na substituição dos defensivos químicos para o tratamento de sementes na agricultura orgânica. Assim, objetivou-se avaliar o crescimento inicial e o controle de fungos associados a sementes de algodoeiro orgânico, através da microbiolização de sementes com Trichoderma sp. e Saccharomyces cerevisiae. Sementes certificadas da cultivar Aroeira, cujo línter havia sido removido com ácido sulfúrico, foram analisadas em delineamento inteiramente casualizado em arranjo fatorial de $5 \times 2+1$, com cinco concentrações $(0 ; 0,5 ; 1,0 ; 1,5$ e 2,0), dois agentes biocontroladores (Trichoderma sp. e S. cerevisiae) e o fungicida como tratamento adicional (Captan ${ }^{\circledast}$ ). Os testes de sanidade, germinação e emergência das sementes foram avaliados para confirmar as hipóteses. A microbiolização das sementes é eficiente na redução da incidência de fungos e no crescimento inicial de plântulas de algodoeiro orgânico cv. Aroeira. Os agentes biocontroladores avaliados são superiores ao tratamento químico no crescimento inicial de plântulas. Trichoderma sp. é o agente mais eficaz, proporcionando alto crescimento inicial de plântulas e redução significativa da incidência de fungos.

Termos para indexação: Gossypium hirsutum, biocontroladores, crescimento inicial, controle biológico, promoção de crescimento.
Journal of Seed Science, v.42 e202042021, 2020

http://dx.doi.org/10.1590/ 2317-1545v42229182
${ }^{*}$ Corresponding author
E-mail: cruz.jmfl@gmail.com

Received: 9/25/2019. Accepted: 3/18/2020.

\footnotetext{
${ }^{1}$ Departamento de Fitotecnia e Ciências Ambientais, Universidade Federal da Paraíba, Caixa Postal 66, 58397-000 - Areia, PB, Brasil.
} 


\section{INTRODUCTION}

One of the biggest obstacles to organic production is finding alternatives for controlling diseases that have as similar effectiveness as the usual agrochemicals. Among the limitations of such production system when applied to cotton culture, Kikuti et al. (2002) point out the difficulty in obtaining seeds with high physical, physiological, and sanitary qualities. These aspects can guarantee the establishment of crops with plant stands that are uniform, vigorous, and free from diseases, directly reflecting on the final yield.

In organic cotton cultivation, as in many other cultures, the seeds are the most efficient object for survival and dissemination of several phytopathogens of economic importance. Therefore, the seeds can introduce such microorganisms in former clean areas, thus establishing the initial cycle of the disease and permanently infesting the field (Silva Flávio et al., 2014). Among the pathogenic fungi associated with cotton seeds, the most important are Fusarium oxysporum f. sp. vasinfectum, Colletotrichum gossypii, C. g. var. cephalosporioides, Rhizoctonia solani, Alternaria spp., Aspergillus spp., Penicillium spp. By affecting seed quality directly, they can cause the death of seedlings before and after emergence, leading to loss of vigor, reduction in germination, and rotting.

In this context, performing seed microbiolization with biocontrol agents as part of the integrated disease management is a valuable strategy for organic agriculture, due to its potential for controlling pathogenic microorganisms. The biocontrol agents help to minimize production losses related to phytopathogens through multiple natural processes, such as mycoparasitism, antibiosis, competition, and induced resistance (Xu et al., 2011).

Considering the biocontrol agents, Trichoderma spp. is the most researched and studied fungal genus worldwide. It is considered a key biocontrol microorganism due to its active antagonism against several phytopathogens, which can positively influence seed germination and vegetative growth (Saito et al., 2009). Yeasts have also been used as biocontrol agents, as they are part of the epiphytic and endophytic microbiota, and compete with phytopathogenic agents, through several antagonistic mechanisms (Mello et al., 2011). Among them, research has drawn attention to the enormous biocontrol potential of the genus Saccharomyces spp. (Heling et al., 2017).

Therefore, the microbiotization of seeds emerges as a feasible alternative for controlling phytopathogens in organic production systems. Nevertheless, studies are still on demand to contrast the effect of these biocontrol agents with agrochemicals traditionally used in seed treatment. On that account, the present work aimed at evaluating the initial growth and control of fungi associated with organic cotton seeds (cv. Aroeira), after their microbiotization with Trichoderma sp. and Saccharomyces cerevisiae.

\section{MATERIAL AND METHODS}

The experiment was carried out in the Laboratory of Phytopathology (LAFIT) of the Department of Plant Sciences and Environmental Sciences at the Federal University of Paraíba (UFPB) - city of Areia, state of Paraíba, Brazil.

Certified organic cotton seeds of the cultivar Aroeira were provided by the Brazilian Agricultural Research Corporation (EMBRAPA). First, they had the linter removed though wet sulfuric acid delinting $\left(\mathrm{H}_{2} \mathrm{SO}_{4}\right)$. Next, they were analyzed in compliance with a completely randomized design, in a $5 \times 2+1$ factorial scheme, corresponding to five concentrations, two biocontrol agents, and the fungicide (additional treatment).

The biocontrol agents tested were the yeast Saccharomyces cerevisiae and the fungus Trichoderma sp. The former came from the commercial dry yeast Blaupan ${ }^{\circledR}$, whose instantaneous formula is based on S. cerevisiae. In turn, the isolate of Trichoderma sp. (CMLTO05) belonged to the microorganism collection of the LAFIT - UFPB, and it had been first obtained from seeds of Leucaena leucocephala. The selection of this isolate was based on previous studies. For the experiments, pure cultures of the fungus were reactivated and multiplied in a potato-dextrose-agar medium (PDA). They were maintained inside an incubation chamber for eight days, at $25 \pm 2{ }^{\circ} \mathrm{C}$, and a 12-hour photoperiod.

The action of seed microbiotization on fungal incidence was appraised by the blotter test (Brasil, 2009) using 200 
seeds. They were divided into 10 replications of 20 units, which were individually distributed on Petri dishes $(\varnothing 15$ $\mathrm{cm}$ ), following aseptic conditions. Each dish contained a double-layer filter paper that was previously sterilized and moistened with $10 \mathrm{~mL}$ sterile distilled water (SDW). The inoculation of the biocontrol agents was done in suspension for five minutes. Trichoderma sp. suspensions were attained by adding $10 \mathrm{~mL}$ of SDW in each Petri dish containing the pure colonies. Then, with the aid of a soft brush, the conidia were released and filtered through a sterilized double gauze. The final conidial concentration was determined in a Neubauer chamber set at 0.5, 1.0, 1.5, and $2.0 \times 10^{7} \mathrm{conidia}^{\mathrm{mL}} \mathrm{m}^{-1}$.

The suspension of $S$. cerevisiae was concocted by weighing the biological product in an analytical balance $(0.001$

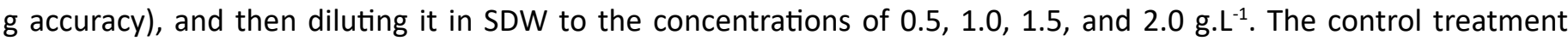
comprised seeds submerged in a $1 \%$ sodium hypochlorite solution for three minutes. For comparison purposes, an additional treatment was performed, with the application of the fungicide Captan ${ }^{\circledR}$ at the dose of $240 \mathrm{~g}$ of the product per $100 \mathrm{~kg}$ of seeds. The dishes were incubated in a growth chamber, Biochemical Oxygen Demand type (BOD), for eight days, at $25 \pm 2{ }^{\circ} \mathrm{C}$ temperature, and a 12-hour photoperiod. Ultimately, an optical microscope and specialized literature (Seifert et al., 2011) were used to identify and determine the incidence of fungi in the seeds. The results were expressed in percentage of fungal occurrence.

The initial seedling growth was assessed through the germination and emergence tests, performed on four replications of 50 microbiolized seeds, according to Brasil (2009). The emergence test was conducted in a greenhouse, and the seeds were sown in plastic trays dimensioned $66 \times 33 \times 6 \mathrm{~cm}$, containing washed, previously sterilized sand. These sets were watered twice a day. For the germination test, the seeds were distributed on sterilized germitest paper sheets, which were moistened at 2.5 times the dry paper weight. After sowing, the papers were wrapped in rolls, put inside transparent plastic bags, and then placed in a BOD germination chamber, set at $25 \pm 2{ }^{\circ} \mathrm{C}$ and a 12 -hour photoperiod.

The number of seed germinated and emerged (cotyledon above the ground) were recorded daily from the $4^{\text {th }}$ to the $12^{\text {th }}$ day after sowing - the germination test considered both the normal seedlings (root and hypocotyl) and the abnormal ones. The results were expressed in percentage. The first germination and emergence counts were done together with the tests, which allowed to calculate the germination and emergence speed indices (GSI and ESI, respectively), according to the formula proposed by Maguire (1962).

The length and dry mass of seedlings were assessed in both tests individually. With a digital caliper (0.001 mm accuracy), the length of the shoot and root of the seedlings was gauged, and the results were delivered in centimeters. Subsequently, shoots and roots were separately packed in Kraft paper bags, and then taken to a forced air convection oven set at $65^{\circ} \mathrm{C}$ for $48 \mathrm{~h}$. After that time, having the samples reached a constant weight, the dry mass of each seedling part was weighed in an analytical balance ( $0.001 \mathrm{~g}$ accuracy), and the results were expressed in grams.

The statistical analysis was handled with the software R (R Core Team, 2019), and the results were submitted to analysis of variance and polynomial regression, in which the linear and quadratic models were tested. The mean values of each biocontrol agent were contrasted at each concentration level by the F-test ( $p \leq 0.05)$, and the treatments were compared with the fungicide by the Dunnett's test $(p \leq 0.05)$. The values of fungus incidence were transformed in $(\sqrt{ } x+1)$ beforehand.

\section{RESULTS AND DISCUSSION}

Table 1 reports the effect of the biocontrol agents on fungal incidence. The following fungus genera were identified: Alternaria sp., Aspergillus sp., Chaetomium sp., Cladosporium sp., Colletotrichum sp., Fusarium sp., Macrophomina sp., Nigrospora sp., and Phoma sp. The high occurrence of phytopathogenic fungi in the organic cotton seeds evidences that the treatments were crucial for minimizing the damages these microorganisms might cause in all culture phases. As stated by Machado et al. (2012), the primary advantage of employing biocontrol agents is their contribution to a steadier regulation of diseases. Over the years, this can alter the agroecosystem equilibrium, making it inhospitable for pathogen development, without causing, however, significant impacts on the overall environment. 
Table 1. Incidence of fungi associated with organic cotton seeds treated with Trichoderma sp. (TCH) and Saccharomyces cerevisiae $(\mathrm{SCH})$.

\begin{tabular}{|c|c|c|c|c|c|c|}
\hline \multirow[b]{2}{*}{ Concentration } & \multicolumn{2}{|c|}{ Fusarium sp. (\%) } & \multicolumn{2}{|c|}{ Cladosporium sp. (\%) } & \multicolumn{2}{|c|}{ Chaetomium sp. (\%) } \\
\hline & $\begin{array}{c}\text { TCH } \\
\left(10^{7} \text { conidia. } \mathrm{mL}^{-1}\right)\end{array}$ & $\begin{array}{l}\mathrm{SCH} \\
\left(\mathrm{g} \cdot \mathrm{L}^{-1}\right)\end{array}$ & $\begin{array}{c}\mathrm{TCH} \\
\left(10^{7} \text { conidia. } \mathrm{mL}^{-1}\right)\end{array}$ & $\begin{array}{c}\mathrm{SCH} \\
\left(\mathrm{g} \cdot \mathrm{L}^{-1}\right)\end{array}$ & $\begin{array}{c}\mathrm{TCH} \\
\left(10^{7} \text { conidia. } \mathrm{mL}^{-1}\right)\end{array}$ & $\begin{array}{l}\mathrm{SCH} \\
\left(\mathrm{g} \cdot \mathrm{L}^{-1}\right)\end{array}$ \\
\hline 0 & $52 a^{*}$ & $52 a^{*}$ & $33 a^{*}$ & $33 a^{*}$ & $20 a^{*}$ & $20 a^{*}$ \\
\hline 0.5 & $7 a^{*}$ & $3 \mathrm{~b}$ & $2 \mathrm{a}$ & $3 a$ & $0 \mathrm{a}$ & $0 \mathrm{a}$ \\
\hline 1.0 & $4 a$ & $2 \mathrm{a}$ & $0 \mathrm{a}$ & $1 \mathrm{a}$ & $0 \mathrm{a}$ & $0 \mathrm{a}$ \\
\hline 1.5 & $0 \mathrm{a}$ & $2 a$ & $0 \mathrm{a}$ & $2 a$ & $0 \mathrm{a}$ & $0 \mathrm{a}$ \\
\hline 2.0 & $0 \mathrm{a}$ & $1 \mathrm{a}$ & $0 \mathrm{a}$ & $1 \mathrm{a}$ & $0 \mathrm{a}$ & $0 \mathrm{a}$ \\
\hline Captan $^{\circledR}$ & $0 \mathrm{a}$ & $0 \mathrm{a}$ & $0 \mathrm{a}$ & $0 \mathrm{a}$ & $0 \mathrm{a}$ & $0 \mathrm{a}$ \\
\hline \multirow[t]{2}{*}{ CV (\%) } & \multicolumn{2}{|c|}{25.80} & \multicolumn{2}{|c|}{25.09} & \multicolumn{2}{|c|}{34.44} \\
\hline & \multicolumn{2}{|c|}{ Aspergillus sp. (\%) } & \multicolumn{2}{|c|}{ Nigrospora sp. (\%) } & \multicolumn{2}{|c|}{ Phoma sp. (\%) } \\
\hline Concentration & $\begin{array}{c}\text { TCH } \\
\left(10^{7} \text { conidia. } \mathrm{mL}^{-1}\right)\end{array}$ & $\begin{array}{l}\mathrm{SCH} \\
\left(\mathrm{g} \cdot \mathrm{L}^{-1}\right)\end{array}$ & $\begin{array}{c}\mathrm{TCH} \\
\left(10^{7} \text { conidia. } \mathrm{mL}^{-1}\right)\end{array}$ & $\begin{array}{l}\mathrm{SCH} \\
\left.\text { (g. } \mathrm{L}^{-1}\right)\end{array}$ & $\begin{array}{c}\text { TCH } \\
\left(10^{7} \text { conidia. } \mathrm{mL}^{-1}\right)\end{array}$ & $\begin{array}{l}\mathrm{SCH} \\
\left(\mathrm{g} \cdot \mathrm{L}^{-1}\right)\end{array}$ \\
\hline 0 & $42 a^{*}$ & $42 a^{*}$ & $13 a^{*}$ & $13 a^{*}$ & $11 a^{*}$ & $11 a^{*}$ \\
\hline 0.5 & $23 b^{*}$ & $34 a^{*}$ & $0 \mathrm{a}$ & $0 \mathrm{a}$ & $0 \mathrm{a}$ & $0 \mathrm{a}$ \\
\hline 1.0 & $10 b^{*}$ & $23 a^{*}$ & $0 \mathrm{a}$ & $0 \mathrm{a}$ & $0 \mathrm{a}$ & $0 \mathrm{a}$ \\
\hline 1.5 & $5 b$ & $21 a^{*}$ & $0 \mathrm{a}$ & $0 \mathrm{a}$ & $0 \mathrm{a}$ & $0 \mathrm{a}$ \\
\hline 2.0 & $5 b$ & $12 a^{*}$ & $0 \mathrm{a}$ & $0 \mathrm{a}$ & $0 \mathrm{a}$ & $0 \mathrm{a}$ \\
\hline Captan $^{\circledR}$ & $0 \mathrm{a}$ & $0 \mathrm{a}$ & $0 \mathrm{a}$ & $0 \mathrm{a}$ & $0 \mathrm{a}$ & $0 \mathrm{a}$ \\
\hline \multirow[t]{2}{*}{ CV (\%) } & \multicolumn{2}{|c|}{31.37} & \multicolumn{2}{|c|}{21.73} & \multicolumn{2}{|c|}{23.52} \\
\hline & \multicolumn{2}{|c|}{ Macrophomina sp. (\%) } & \multicolumn{2}{|c|}{ Colletotrichum sp. (\%) } & \multicolumn{2}{|c|}{ Alternaria sp. (\%) } \\
\hline Concentration & $\begin{array}{c}\text { TCH } \\
\left(10^{7} \text { conidia. } \mathrm{mL}^{-1}\right)\end{array}$ & $\begin{array}{c}\mathrm{SCH} \\
\left(\mathrm{g} \cdot \mathrm{L}^{-1}\right) \\
\end{array}$ & $\begin{array}{c}\text { TCH } \\
\left(10^{7} \text { conidia. } \mathrm{mL}^{-1}\right)\end{array}$ & $\begin{array}{l}\mathrm{SCH} \\
\left(\mathrm{g} \cdot \mathrm{L}^{-1}\right)\end{array}$ & $\begin{array}{c}\text { TCH } \\
\left(10^{7} \text { conidia. } \mathrm{mL}^{-1}\right)\end{array}$ & $\begin{array}{c}\mathrm{SCH} \\
\left(\mathrm{g} \cdot \mathrm{L}^{-1}\right) \\
\end{array}$ \\
\hline 0 & 10 a* & $10 a^{*}$ & 10 a* & $10 a^{*}$ & $9 a^{*}$ & 9 a* \\
\hline 0.5 & $0 \mathrm{a}$ & $0 \mathrm{a}$ & $0 \mathrm{a}$ & $0 \mathrm{a}$ & $0 \mathrm{a}$ & $0 \mathrm{a}$ \\
\hline 1.0 & $0 \mathrm{a}$ & $0 \mathrm{a}$ & $0 \mathrm{a}$ & $0 \mathrm{a}$ & $0 \mathrm{a}$ & $0 \mathrm{a}$ \\
\hline 1.5 & $0 \mathrm{a}$ & $0 \mathrm{a}$ & $0 \mathrm{a}$ & $0 \mathrm{a}$ & $0 \mathrm{a}$ & $0 \mathrm{a}$ \\
\hline 2.0 & $0 \mathrm{a}$ & $0 \mathrm{a}$ & $0 \mathrm{a}$ & $0 \mathrm{a}$ & $0 \mathrm{a}$ & $0 \mathrm{a}$ \\
\hline Captan $^{\circledR}$ & $0 \mathrm{a}$ & $0 \mathrm{a}$ & $0 \mathrm{a}$ & $0 \mathrm{a}$ & $0 \mathrm{a}$ & $0 \mathrm{a}$ \\
\hline CV (\%) & \multicolumn{2}{|c|}{28.12} & \multicolumn{2}{|c|}{23.52} & \multicolumn{2}{|c|}{22.77} \\
\hline
\end{tabular}

Means followed by the same letter in the row do not differ statistically, according to the F-test ( $\leq \leq 0.05)$; and *: mean statistically differs from the commercial fungicide, according to Dunnett's test $(p \leq 0.05)$. Means transformed in $v x+1$. CV: Coeffcient of variation.

The microbiolization with Trichoderma sp. $(\mathrm{TCH})$ and S. cerevisiae $(\mathrm{SCH})$, at the levels tested, proved to be efficient at lowering the incidence of the identified fungus genera. Except for Fusarium sp. and Aspergillus sp., all concentrations proved to be as successful as the agrochemical.

Although the antagonistic effect of the yeast can be attributed to the competition for nutrients, an antibiosis relationship might occur with the fungi. Such relation, based on chemical interference, may include the production of enzymes that affect the fungal cell wall, such as glucanases. Antibiosis can also occur as a result of predatory activity, in which case the yeast produces extracellular glycolipids or glycoproteins with fungicidal or fungistatic activity (Golubev, 2006). 
S. cerevisiae at $0.5 \mathrm{~g} . \mathrm{L}^{-1}$ produced a greater decrease in Fusarium sp. incidence in comparison to Trichoderma sp. at $0.5 \times 10^{7}$ conidia. $\mathrm{mL}^{-1}$. The latter treatment also performed worse than the commercial product. Differently, the other concentrations acted similarly to the agrochemical, and the bioagents significantly reduced the pathogenic fungus alike.

As for the control of Aspergillus sp., Trichoderma sp. was significantly more efficient than S. cerevisiae. In fact, at 1.5 and $2.0 \times 10^{7}$ conidia. $\mathrm{mL}^{-1}$, the biocontrol fungus caused $88 \%$ reduction, a rate similar to the agrochemical.

Trichoderma sp. can exert a biocontrol activity directly (through predation or production of growth inhibitors) or indirectly. The latter case happens when the colonized plants have high endogenous levels of auxins, ethylene, gibberellins, plant enzymes, antioxidants, solutes, and compatible compounds, such as phytoalexins and phenols. These substances furnish them with tolerance to induced biotic and abiotic stresses (López-Bucio et al., 2015).

All concentrations tested of Trichoderma sp. and S. cerevisiae decreased by $100 \%$ the incidence of Alternaria sp., Chaetomium sp., Colletotrichum sp., Macrophomina sp., Nigrospora sp., and Phoma sp.

Regarding the initial growth variables, neither the emergence nor the germination and emergence speed indices showed significant alteration with the application of the biocontrol agents. In the first germination count (FGC), no significant difference was observed between the biocontrol agents at the levels tested. However, for Trichoderma sp., this rate gradually increased, as the concentrations increased. Particularly, at $2.0 \times 10^{7}$ conidia. $\mathrm{mL}^{-1}$, it even surpassed the chemical treatment and scored $98.5 \%$ (Figure $1 \mathrm{~A}$ ).
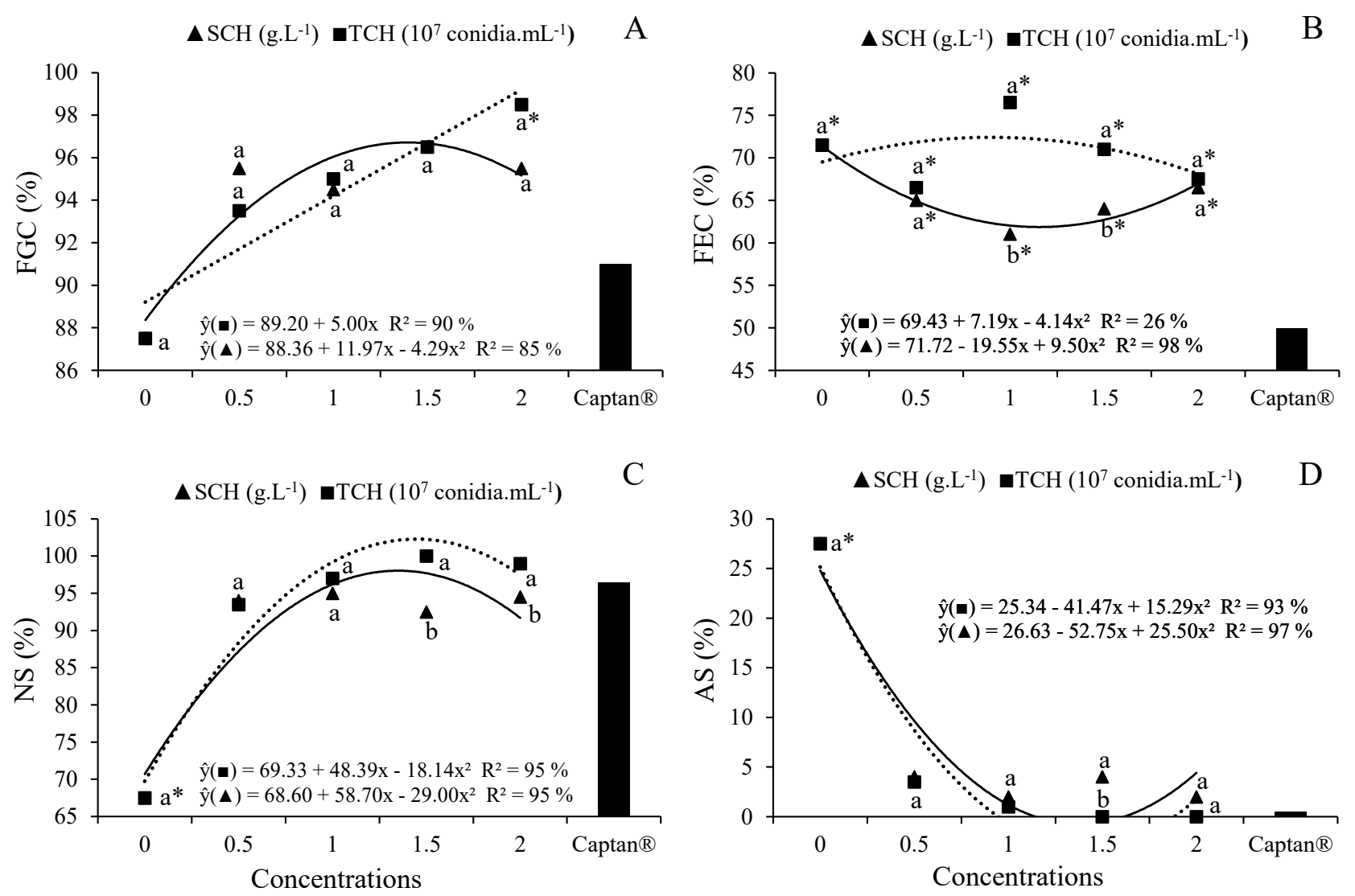

Means accompanied by the same letter, at a given concentration, do not differ statistically according to the F-test ( $p \leq 0.05)$; and $*$ : mean statistically differs from the commercial fungicide, according to Dunnett's test $(p \leq 0.05)$.

Figure 1. Results of first germination count (FGC), first emergence count (FEC), normal seedlings (NS), and abnormal seedlings (AS) obtained in the germination test of organic cotton seeds treated with Trichoderma sp. (TCH) and Saccharomyces cerevisiae (SCH). 
All levels of both Trichoderma sp. and S. cerevisiae exhibited values of first emergence count (FGC) significantly higher than the fungicide. Also, when the control agents were contrasted, only the concentrations of 1.0 and 1.5 $\times 10^{7}$ conidia. $\mathrm{mL}^{-1}$ of the fungus showed a statistical difference from the yeast. The highest (76.5\%) and lowest (61\%) average values of FGC corresponded to $1.0 \times 10^{7}$ conidia. $\mathrm{mL}^{-1}$ of Trichoderma sp. and $1.0 \mathrm{~g} . \mathrm{L}^{-1}$ of S. cerevisiae, respectively (Figure 1B).

In the analyses of normal (NS) and abnormal (AS) seedlings, the concentrations of both Trichoderma sp. and $S$. cerevisiae attained effects similar to the chemical product - except for the control treatment, which presented the lowest NS and the highest AS values (67.5\% and 27.5\%, respectively) (Figures 1C and 1D). As their concentrations increased, the biocontrol agents exhibited meaningful differences between them, as for the production of NS (Figure 1C). Considering the formation of AS, only S. cerevisiae $1.5 \mathrm{~g}^{-\mathrm{L}^{-1}}$ showed a significant difference in comparison with Trichoderma sp. at $1.5 \times 10^{7}$ conidia. $\mathrm{mL}^{-1}$ (Figure 1D).

Overall, the concentrations of Trichoderma sp. showed attribute numbers statistically superior to those of $S$. cerevisiae. The only exception concerns the shoot dry mass obtained in germination (SDMG), in which the fungus at 2.0 $\times 10^{7}$ conidia. $\mathrm{mL}^{-1}$ was no different from the yeast at $2.0 \mathrm{~g} \cdot \mathrm{mL}^{-1}$. Moreover, the biocontrol agents, at all concentrations tested, performed better than the conventional agrochemical (Figure 2).

The vegetative growth response triggered by Trichoderma spp. has been acknowledged, as these microorganisms are capable of solubilizing phosphate and other minerals, making them available to plants, and also producing auxin
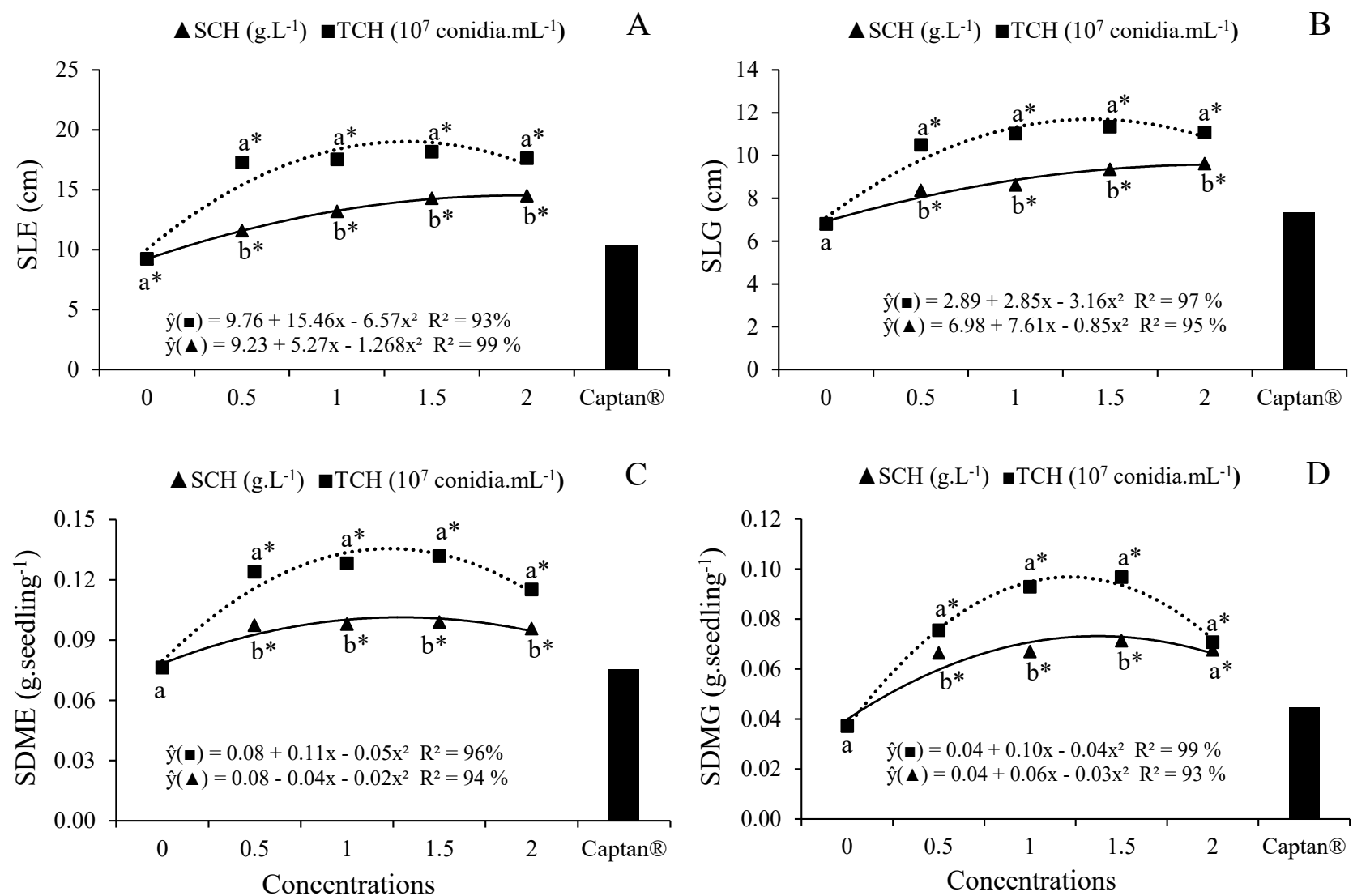

Means accompanied by the same letter, at a given concentration, do not differ statistically according to the F-test ( $p \leq 0.05)$; and *: mean statistically differs from the commercial fungicide, according to Dunnett's test ( $p \leq 0.05)$.

Figure 2. Shoot length found in the germination (SLG) and emergence (SLE) tests and shoot dry mass obtained in the germination (SDMG) and emergence (SDME) tests of organic cotton seedlings treated with Trichoderma sp. (TCH) and Saccharomyces cerevisiae ( $\mathrm{SCH})$. 
analogs (Vinale et al., 2008). The performance of the plant can also be enhanced as a result of the release of plant growth regulators by yeasts (El-Tarabily and Sivasithamparam, 2006), including indole-3-acetic acid (IAA), indole-3pyruvic acid (IPA), gibberellins, and polyamines (El-Tarabily and Sivasithamparam, 2006; Cloete et al., 2009).

The Trichoderma sp. suspension at $1.5 \times 10^{7}$ conidia. $\mathrm{mL}^{-1}$ delivered the highest values of shoot length in germination (SLG; $11.35 \mathrm{~cm}$ ) and shoot dry mass in both germination (SDMG; $0.097 \mathrm{~g}$ ) and emergence (SDME; $0.132 \mathrm{~g}$ ) (Figures 2B, $2 \mathrm{C}$, and $2 \mathrm{D}$ ). However, the concentration of $2.0 \times 10^{7}$ conidia. $\mathrm{mL}^{-1}$ was responsible for the highest shoot length in the emergence (SLE; $18.17 \mathrm{~cm}$ ) (Figure 2A).

Regarding the variables related to root development, Trichoderma sp. proved to be more effective than the agrochemical in all concentrations tested (Figure 3). This effect was equally observed in S. cerevisiae for the attributes root length (RLG) and root dry mass (RDMG), both in germination (Figures 3B and 3D). According to López-Bucio et al. (2015), the radicular development prompted by Trichoderma sp. is connected with a series of compounds released by the mycelium. Some of these elements stimulate root branching, thus improving the absorption of nutrients and water, which ultimately leads to root growth. Another beneficial factor is the exudation of substances, such as siderophores and organic acids, which increase the availability of nutrients (Zhao et al., 2014).

The RLG and RLE (root length in germination and emergence, respectively) allowed to verify that, at all concentrations, Trichoderma sp. caused a significantly better development than S. cerevisiae (Figures 3A and 3B). Regarding the RDME (root dry mass in the emergence), the concentrations of Trichoderma sp. also performed statistically better than $S$.
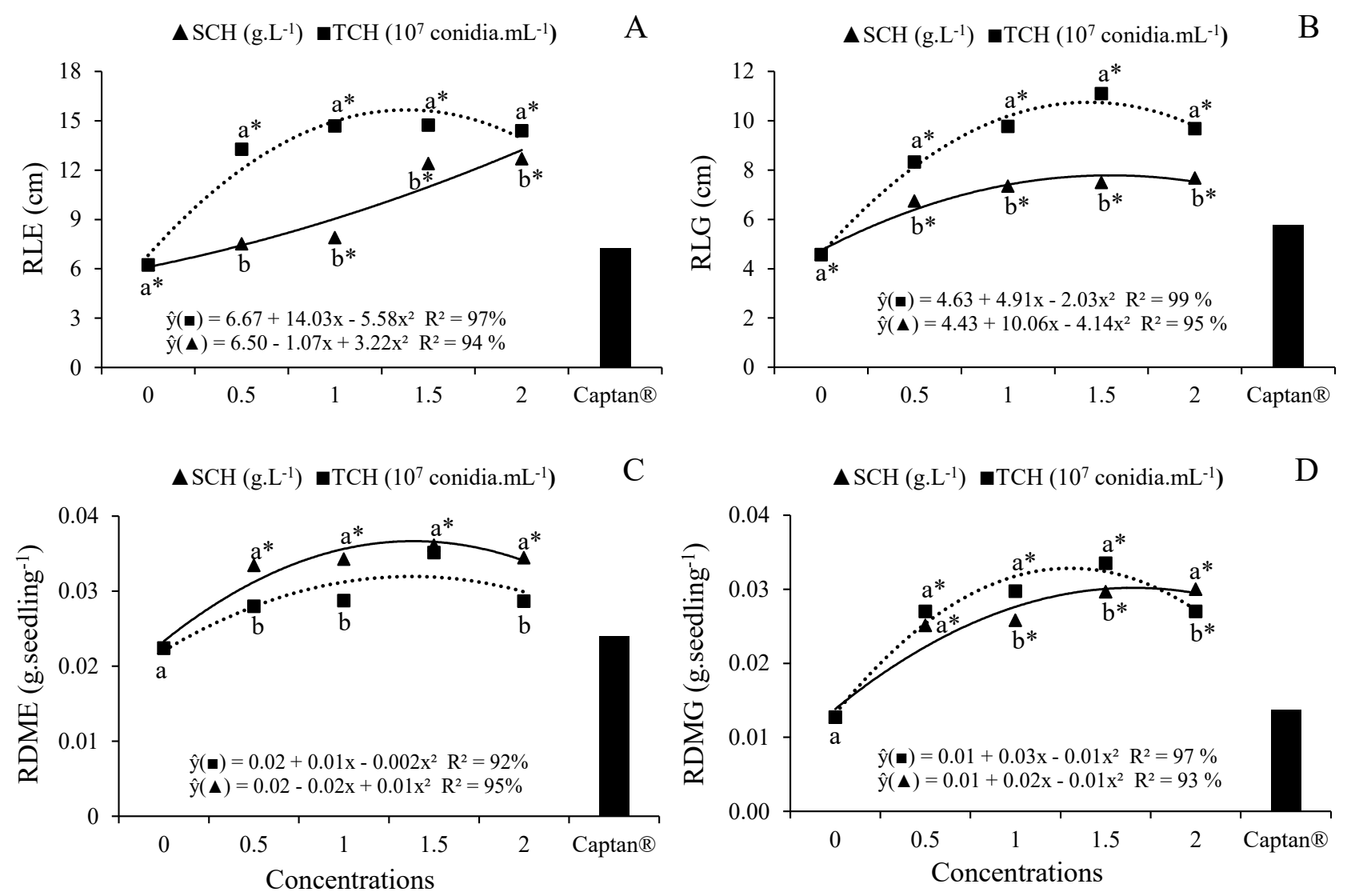

Means accompanied by the same letter, at a given concentration, do not differ statistically according to the F-test ( $p \leq 0.05)$; and *: mean statistically differs from the commercial fungicide, according to Dunnett's test ( $p \leq 0.05)$.

Figure 3. Root length in germination (RLG) and emergence (RLE) tests and root dry mass in germination (RDMG) and emergence (RDME) of organic cotton seedlings treated with Trichoderma sp. (TCH) and Saccharomyces cerevisiae $(\mathrm{SCH})$. 
cerevisiae. However, the treatments at $1.5 \times 10^{7}$ conidia. $\mathrm{mL}^{-1}$ of the fungus and $1.5 \mathrm{~g} . \mathrm{L}^{-1}$ of the yeast led to a similar result (Figure $3 C$ ). The RDMG showed a gradual accumulation of mass, as the concentrations of $S$. cerevisiae increased. Moreover, at $2.0 \mathrm{~g} . \mathrm{L}^{-1}$, the yeast surpassed the treatment with $2.0 \times 10^{7}$ conidia. $\mathrm{mL}^{-1}$ of the fungus, reaching an RDMG value of $0.03 \mathrm{~g}$ (Figure 3D).

An increasing number of studies indicate that the growth of roots can be enhanced directly or indirectly by yeasts existing in the rhizosphere (El-Tarabily and Sivasithamparam, 2006; Cloete et al., 2009). Besides, organic and inorganic fertilizers, made up by a combination of yeasts, are capable of reestablishing the sustainability of ecosystems, as well as boosting the productivity of farmlands.

The suspension of Trichoderma sp. at $1.5 \times 10^{7}$ conidia. $\mathrm{mL}^{-1}$ resulted in the most expressive values of RLG (11.10 $\mathrm{cm}), \operatorname{RLE}(14.75 \mathrm{~cm}), \operatorname{RDMG}(0.034 \mathrm{~g})$, and RDME $(0.035 \mathrm{~g})$. Nevertheless, at $1.5 \mathrm{~g} . \mathrm{L}^{-1}, \mathrm{~S}$. cerevisiae also provided a high $\operatorname{RDME}(0.036 \mathrm{~g})$.

\section{CONCLUSIONS}

Seed microbiolization is effective at diminishing both incidence and initial growth of fungi in organic cotton seedlings cv. Aroeira. The biocontrol agents considered in this study perform better than the chemical treatment, regarding the initial seedling growth. Trichoderma sp. is the most effective agent, as it provides high initial seedling growth and a significant decrease in fungal occurrence.

\section{REFERENCES}

BRASIL. Ministério da Agricultura, Pecuária e Abastecimento. Regras para análise de sementes. Ministério da Agricultura, Pecuária e Abastecimento. Secretaria de Defesa Agropecuária. Brasília: MAPA, 2009. 395p. https://www.abrates.org.br/files/regras_analise_ de_sementes.pdf

CLOETE, K.J.; VALENTINE, A.J.; STANDER, M.A.; BLOMERUS, L.M.; BOTHA, A. Evidence of symbiosis between the soil yeast Cryptococcus laurentii and a sclerophyllous medicinal shrub, Agathosma betulina (Berg.) Pillans. Microbial Ecology, v.57, n.4, p.624-632, 2009. https://doi.org/10.1007/s00248-008-9457-9

EL-TARABILY, K.A.; SIVASITHAMPARAM, K. Potential of yeasts as biocontrol agents of soil-borne fungal plant pathogens and as plant growth promoters. Mycoscience, v.47, n.1, p.25-35, 2006. https://doi.org/10.1007/S10267-005-0268-2

GOLUBEV, W.I. Antagonistic interactions among yeasts. In: Biodiversity and ecophysiology of yeasts. Springer, Berlin, Heidelberg, 2006. p.197-219. https://doi.org/10.1007/3-540-30985-3_10

HELING, A.L.; KUHN, O.J.; STANGARLIN, J.R.; HENKEMEIER, N.P., COLTRO-RONCATO, S.; GONÇALVES, E.D. Controle biológico de antracnose em pós-colheita de banana "Maçã" com Saccharomyces spp. Summa Phytopathologica, v.43, n.1, p.49-51, 2017. https://doi.org/10.1590/0100-5405/2105

KIKUTI, A.L.P.; OLIVEIRA, J.A.; MEDEIROS-FILHO, S.; FRAGA, A.C. Armazenamento e qualidade fisiológica de sementes de algodão submetidas ao condicionamento osmótico. Ciência e Agrotecnologia, v.26, n.2, p.439-443, 2002. http://www.editora.ufla.br/index.

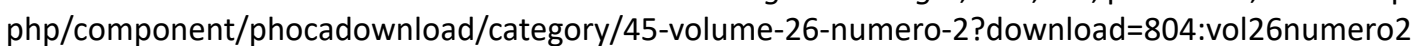

LÓPEZ-BUCIO, J.; PELAGIO-FLORES, R.; HERRERA-ESTRELLA, A. Trichoderma as biostimulant: exploiting the multilevel properties of a plant beneficial fungus. Scientia Horticulturae, v.196, p.109-123, 2015. https://doi.org/10.1016/j.scienta.2015.08.043

MACHADO, D.F.M.; PARZIANELLO, F.R.; SILVA, A.C.F.D.; ANTONIOLLI, Z.I. Trichoderma no Brasil: o fungo e o bioagente. Revista de Ciências Agrárias, v.35, n.1, p.274-288, 2012. https://doi.org/10.19084/rca.16182

MAGUIRE, J.D. Speed of germination aid in selection and evaluation of seedling emergence and vigor. Crop Science, v.2, n.1, p.176177, 1962. https://dl.sciencesocieties.org/publications/cs/abstracts/2/2/CS0020020176

MELLO, M.R.F.; SILVEIRA, E.B.; VIANA, I.O.; GUERRA, M.L.; MARIANO, R.L.R. Uso de antibióticos e leveduras para controle da podridãomole em couve-chinesa. Horticultura Brasileira, v.29, n.1, p.78-83, 2011. https://doi.org/10.1590/S0102-05362011000100013 
R CORE TEAM. R: A language and environment for statistical computing. R Foundation for Statistical Computing, Vienna, Austria, 2019. https://www.R-project.org/

SAITO, L.R.; SALES, L.L.S.R.; MARTINCKOSKI, L.; ROYER, R.; RAMOS, M.S.; REFFATTI, T. Aspects of the effects of the fungus Trichoderma spp. in biocontrol of pathogens of agricultural crops. Applied Research and Agrotechnology, v.2, n.3, p.203-216, 2009. https:// revistas.unicentro.br/index.php/repaa/article/download/1515/1393

SEIFERT, K.; MORGAN-JONES, G.; GAMS, W.; KENDRICK, B. The genera of Hyphomycetes. CBS-KNAW Fungal Biodiversity Centre, Utrecht, 2011. 997p.

SILVA FLÁVIO, N.S.D.; SALES, N.D.L.P.; AQUINO, C.F.; SOARES, E.P.S.; AQUINO, L.F.S.; CATÃO, H.C.R.M. Qualidade sanitária e fisiológica de sementes de sorgo tratadas com extratos aquosos e óleos essenciais. Semina: Ciências Agrárias, v.35, n.1, p.7-20, 2014. http:// dx.doi.org/10.5433/1679-0359.2014v35n1p7

VINALE, F.; SIVASITHAMPARAM, K.; GHISALBERTI, E.L.; MARRA, R.; WOO, S.L.; LORITO, M. Trichoderma-plant-pathogen interactions. Soil Biology and Biochemistry, v.40, n.1, p.1-10, 2008. https://doi.org/10.1016/j.soilbio.2007.07.002

XU, X.M.; JEFFRIES, P.; PAUTASSO, M.; JEGER, M.J. Combined use of biocontrol agents to manage plant diseases in theory and practice. Phytopathology, v.101, n.9, p.1024-1031, 2011. https://doi.org/10.1094/PHYTO-08-10-0216

ZHAO, L.; WANG, F.; ZHANG, Y.; ZHANG, J. Involvement of Trichoderma asperellum strain T6 in regulating iron acquisition in plants. Journal of Basic Microbiology, v.54, n.S1, p.115-124, 2014. https://doi.org/10.1002/jobm.201400148 use, distribution, and reproduction in any medium, provided the original work is properly cited. 